OPEN ACCESS

\title{
Foraging behaviour of Cape gannets as an indicator of colony health status
}

\author{
Ralf H. E. Mullers ${ }^{1,2, *}$, René A. Navarro \\ ${ }^{1}$ University of Groningen, Department of Behavioural Biology, PO Box 14, 9750 AA Haren, The Netherlands \\ ${ }^{2}$ Animal Demography Unit, Department of Zoology, University of Cape Town, Rondebosch 7701, South Africa
}

\begin{abstract}
From 2003 to 2007, a total of 646 breeding Cape gannets Morus capensis were equipped with GPS-loggers at 2 colonies to obtain insight into how the foraging behaviour of gannets varied between colonies and whether it could predict the 'health' of these colonies, i.e. the growth rate. The foraging behaviour of gannets from Malgas Island, South Africa, varied considerably during the breeding season; average trip duration could double from week to week. At Ichaboe Island, Namibia, foraging behaviour varied less, but the gannets made $2.3 \mathrm{~h}$ longer trips and had a larger foraging area than the gannets from Malgas. Gannets scavenging for fishery discards made shorter foraging trips and spent less time flying than birds foraging for live prey. Utilisation of fishery discards was more prominent at Malgas. Chicks from Ichaboe grew faster and had higher survival rates, possibly associated with the larger proportion of live prey in their diet. The fraction of time flown during foraging trips was positively associated with chick growth in the colony, probably because gannets that made longer trips were more likely to return with good quality live prey. Variations in food availability, fitness trade-offs, predation pressures and inter-individual specialisation might explain why our results contradict a previously described relationship between parental foraging behaviour and colony status. The study of parental behaviour is important to explain chick growth, a component of colony health status, but it is inadequate to predict overall colony health status in Cape gannets.
\end{abstract}

KEY WORDS: Population dynamics · Foraging behaviour $\cdot$ Chick growth $\cdot$ Conservation $\cdot$ Diet

\section{INTRODUCTION}

The status of populations is commonly assessed by establishing population size and/or growth rates, but these can only be generated and interpreted in retrospect (Krebs 2002). Understanding the processes that determine population growth, including adult survival and juvenile recruitment into the breeding colony, requires long-term studies (Lebreton et al. 1992, Pradel et al. 1997). Parameters that can be collected in a short period and have predictive value for population dynamics might enhance the assessment of colony 'health' status, i.e. the population growth rates. It has been suggested that behavioural data can be used as a proxy for colony health and can be linked to population changes (e.g. Krebs 1995, Lewis et al. 2006). Lewis et al. (2006) studied Cape gannets
Morus capensis, a long-lived seabird in which foraging behaviour may influence reproductive success and can, ultimately, be linked to population trends. Cape gannets from colonies decreasing in size worked harder (i.e. made longer foraging trips), brought back less energy to the colony and had lower body condition than birds from growing colonies (Lewis et al. 2006). The authors concluded that 'behavioural and state data can be used to identify important drivers of population change...' (Lewis et al. 2006, p. 606). Here, we reconsidered this hypothesis and assessed whether foraging behaviour of Cape gannets is a predictor of chick growth, a parameter related to population growth rates.

Studies on the relation between parental foraging effort and chick growth or survival have shown that increased effort enhances reproductive output (Puge- 
sek 1995, Wendeln \& Becker 1999, but see Falk et al. 2002, Takahashi et al. 2003 for negative results). Variability in food supply potentially affects the foraging success of seabirds and, thus, their breeding success and eventually population numbers. Cape gannets breed in the Benguela upwelling-system off the west and south coasts of southern Africa and feed mainly on anchovies Engraulis encrasicolus and sardines Sardinops sagax (Berruti et al. 1993, Adams \& Klages 1999). The availability of these prey species on the west coast of southern Africa has decreased considerably in recent years, and, concomitantly, the population numbers of Cape gannets have also decreased (van der Lingen et al. 2005, Crawford et al. 2007). In Namibia, numbers of breeding gannets in 2005 were reduced to only $5 \%$ of their numbers in 1956, and on the west coast of South Africa they decreased by approximately $33 \%$ between 1997 and 2005 (Crawford et al. 2007). Due to these declines, the species has been listed as 'vulnerable' by the International Union for Conservation of Nature (IUCN).

We studied the foraging behaviour of Cape gannets by equipping them with GPS-loggers at 2 breeding colonies during 4 breeding seasons. At the same time, we measured a large sample of chicks to determine growth in both colonies. We tested the hypotheses: (1) that variation in foraging behaviour within a breeding season is associated with chick growth and survival and (2) that such variation may be related to diet shifts. We further speculated on how these findings might relate to population dynamics, which can be an important indicator in conservation and biodiversity management.

\section{MATERIALS AND METHODS}

The Cape gannet Morus capensis is a monomorphic, long-lived seabird that feeds on different fish species by plunge-diving (Nelson 1978). The entire world population breeds on 6 islands, 3 of which are located in Namibia and 3 in South Africa. Currently all 5 colonies on the west coast of southern Africa are decreasing (Crawford et al. 2007). Our data were collected during 4 breeding seasons (2003-2004 to 2006-2007) at Malgas Island (South Africa, $33^{\circ} 03^{\prime} \mathrm{S}, 17^{\circ} 93^{\prime} \mathrm{E}$ ) and during 3 breeding seasons (2004-2005 to 2006-2007) at Ichaboe Island (Namibia, $26^{\circ} 29^{\prime} \mathrm{S}, 14^{\circ} 94^{\prime} \mathrm{E}$ ).

Foraging behaviour of adults. GPS-loggers (Technosmart) recorded geographic positions (95\% of fixes within a radius of $11.6 \mathrm{~m}$; see Steiner et al. 2000 for a full technical description) for 646 Cape gannets on which they were deployed. The loggers were sealed in 2 waterproof polyethylene bags and weighed about $50 \mathrm{~g}$, approximately $2 \%$ of the adult body mass (mean \pm SD: $2531 \pm 194 \mathrm{~g}$ in the present study, $\mathrm{n}=554$ ). Birds with chicks of different ages were selected to carrying the loggers. The gannets were measured (length of the flattened wing chord to the nearest 1 $\mathrm{mm}$ and bill length to the nearest $0.1 \mathrm{~mm}$ ) and weighed (to the nearest $25 \mathrm{~g}$ ). Body condition indices (mass/wing length; see Lewis et al. 2006) were calculated for 2005-2006 and 2006-2007 and compared between the colonies and sexes. The logger was attached to the lower back and tail feathers with waterproof Tesa-tape (Beiersdorf AG), which did not damage the feathers. The procedure took ca. $5 \mathrm{~min}$, after which the birds were released near their nest sites. Similar devices and attachment techniques had no obvious adverse effects on Cape gannet behaviour in previous studies (Grémillet et al. 2004, Lewis et al. 2006). Each nest was monitored once per hour during the daytime. When the parent with the logger returned, it was recaptured and the logger was removed. The birds were then released on their nests where they settled readily. Bill length, wing length and body mass ( $<1 \mathrm{~kg}$ to $5 \mathrm{~g}_{i}>1 \mathrm{~kg}$ to $25 \mathrm{~g}$ ) of each chick were measured to obtain an estimate of its age. Diet samples were collected from focal birds by inverting them over a bucket and qualifying the regurgitated prey (Berruti et al. 1993).

The sexes could not be distinguished in the field. In 2 years (2005-2006 and 2006-2007), we collected some breast feathers of equipped birds, and in retrospect, we determined their sex through DNA analyses (see Fridolfsson \& Ellegren 1999 for detailed methods). The overall sex ratio of sexed birds for which we obtained complete foraging tracks was 0.483 (97 males and 104 females). This ratio did not vary systematically between months (multinominal regression: $\chi^{2}=2.8, p=0.730$ ), so we were confident that, among the gannets we equipped with GPS-loggers, there was no over-representation of one sex that could have biased averages in foraging parameters between periods. For analyses of foraging data, we pooled data for males and females and used the average for both sexes. This entails the implicit assumption that the sexes were also equally represented in the years when sexing was not carried out (2003-2004 and 2004-2005).

In February 2007, we managed to collect only 10 complete tracks at Ichaboe Island. Due to changes in local food availability, gannets left their chicks alone (Mullers \& Tinbergen 2009) and we refrained from further disturbances to the birds for fear of causing them to desert their offspring.

Track analyses. The GPS-loggers were programmed to record the geographic positions of each bird at $10 \mathrm{~s}$ intervals. We took the curved surface of the earth into account by converting the geographic coordinates of 
each GPS fix through the Albers' Equal Area Projection (Snyder 1987). From successive GPS positions of birds $\left(p_{t}=\right.$ position at time $\left.t\right)$, we calculated the distance travelled $\left(D_{t}=\right.$ distance between $p_{t-1}$ and $\left.p_{t}\right)$. While searching for prey, gannets are expected to show less consistent movements in a certain direction than during directional flight and to have increased path sinuosity (e.g. Grémillet et al. 2004). Sinuosity at time $t$ was defined as the ratio between the distance flown (DF) between consecutive GPS positions and the straight line displacement (Di) between the start and end of the sinuosity window $(t \pm 2)$. So, $\mathrm{DF}_{t}=$ $\Sigma \sqrt{ }\left[\left(x_{t-1}-x_{t}\right)^{2}+\left(y_{t-1}-y_{t}\right)^{2}\right]$ for $t=-1$ to $t=2$, and $\mathrm{Di}_{t}=$ $\sqrt{ }\left[\left(x_{t-2}-x_{t+2}\right)^{2}+\left(y_{t-2}-y_{t+2}\right)^{2}\right]$, where $x$ and $y$ correspond with the projected coordinates (in metres) of longitude and latitude, respectively.

By analysing the actual travelling speed and changes in speed and sinuosity, we were able to identify different behaviours of equipped gannets. (1) 'Outflight' signifies the period after the departure from the colony until the sinuosity of the track was $>3.3$; this section is characterised by fast flight (usually $>40 \mathrm{~km}$ $\mathrm{h}^{-1}$ ). (2) 'Return-flight' is the segment of the track after the last hunting activity until the bird is back at the colony. The characteristics are similar to out-flights and are identified by using the same algorithm, traversing the track in reverse order. (3) 'Drifting on the sea surface' is characterised by speeds $<10 \mathrm{~km} \mathrm{~h}^{-1}$. The night was part of this section. At night, gannets sleep on the sea surface and drift along with ocean currents and prevailing winds (Ropert-Coudert et al. 2004). (4) 'Hunting' represents the remaining parts of the track, characterised by medium flight speeds (between 20 and $40 \mathrm{~km} \mathrm{~h}^{-1}$ ) and larger values of sinuosity than outor return-flights.

Foraging areas (i.e. the total area in which foraging activity was recorded) were derived through concave polygon analyses with Ranges6 (Anatrack). Because gannets from Malgas Island would fly around Cape Point, we set the edge restriction to 0.1 , in order to exclude land as part of the foraging area. This analysis does not take the density of the positions into account, but calculates the total area potentially visited by birds.

Chick growth. To obtain an estimate of average chick growth for the colony and at different times during the breeding season, chicks were repeatedly measured at approximately weekly intervals and at several locations around the periphery of the colony. Because growth rates of chicks did not differ between the interior and the periphery of the colony (Mullers et al. 2009a), we minimised disturbance by sampling at the periphery. The chicks were taken from the nest, measured and returned to the nest within $3 \mathrm{~min}$. Bill length, wing length and body mass were measured (as described in previous subsections). Measurements were started at the same time of the day, and chicks were measured in the same sequence by only 2 people (R.H.E.M. and R.A.N.). The measurements continued until the chick either died or fledged. Chicks that hatched within the study sites were included in the measurements to obtain data on the growth of young chicks throughout the breeding season. From the growth data we generated age-independent growth indices to compare growth between years and colonies (Mullers et al. 2009a).

We averaged behavioural variables for each interval between consecutive measurements of chick mass and used these data to analyse the seasonal patterns in parental behaviour and the covariation between parental behaviour and chick growth for each island.

In 2005-2006 we caught and weighed chicks on both islands that were gathered at the edge of the colony and ready to fledge to estimate average fledging weight.

Data analyses. In total, $83.1 \%$ of the foraging tracks were complete $(80.3 \%$ for Malgas and $88.4 \%$ for Ichaboe). The main reason for incomplete tracks was a lack of battery capacity to record the complete foraging trip or gaps in the data because the devices did not establish contact with satellites. To calculate the average foraging parameters, we used complete foraging tracks only (Malgas, $\mathrm{n}=340$; Ichaboe, $\mathrm{n}=198$ ). For the analyses of foraging areas, we also included the incomplete tracks (Malgas, $\mathrm{n}=422$; Ichaboe, $\mathrm{n}=$ 224).

Results are presented as means \pm standard deviation (SD). The foraging data were ln-transformed. After transformation, 2 variables (trip duration and time spent drifting on the sea surface) were not normally distributed and their associations with other variables were tested with non-parametric Kruskal-Wallis tests or Spearman correlations. The other variables were analysed using general linear models (GLMs), in which the potential explanatory effect of variables was tested using a backwards deletion method. The residuals of significant models were tested for normal distribution. Chick growth was analysed in multilevel models to control for repeated measurements of the same individual (individual and observation included as level). Multinomial regressions were used in models with sex or diet as dependent variables. Prey species were categorised in 5 groups: (1) anchovy and sardine, (2) saury Scomberesox saurus, (3) fishery discards (hakes Merluccius capensis and M. paradoxus), (4) other species and (5) a mixture of live prey and fishery discards. Growth indices were calculated using GenStat 8, and statistical analyses were done with MLwiN 2.02 (multilevel models) or the SPSS 14.0 statistical package. 


\section{RESULTS}

\section{Inter- and intra-annual variation in foraging behaviour}

Table 1 provides the means \pm SD of foraging trip parameters for Malgas ( $\mathrm{n}=340$ ) and Ichaboe $(\mathrm{n}=198)$ Islands from 2003-2004 to 2006-2007. The foraging variables (trip duration, total distance, time spent flying, hunting and drifting) were all positively correlated with each other, so we have only described the seasonal variation in trip duration in further detail. The average deployment time of GPS-loggers on Cape gannets Morus capensis during our study was $33.1 \mathrm{~h}$ $( \pm 17.7, \mathrm{n}=620)$.

Gannets from Ichaboe made longer trips during which they covered larger distances, flew more (24\%) and spent more time hunting (32\%) than birds from Malgas (Table 1). During foraging trips gannets from Malgas allocated a larger fraction of their time to drifting on the sea surface than gannets from Ichaboe
(GLM: Island $F_{1,533}=6.7, \mathrm{p}=0.010$; Year $F_{3,533}=21.4$, $\mathrm{p}<0.001)$.

On Malgas, the average trip duration increased by $19 \%$ over the 4 years, but did not vary significantly between years (Table 1b). Total distance increased by $15 \%$ over the same period, from 423 to $486 \mathrm{~km}$. Time allocation during foraging trips changed after 20042005; in 2005-2006 and 2006-2007, the percentage of time flying and the time allocated to foraging activities were reduced and birds spent $36 \%$ more time drifting at the sea surface (Table $1 \mathrm{~b}$ ). Within years there was substantial variation in foraging behaviour on Malgas. To give an indication of the variation observed from week to week, we present average foraging variables for November 2005. In the first 2 weeks of the month, gannets made foraging trips of $20.8 \mathrm{~h}( \pm 13.4)$, flying $349 \mathrm{~km}( \pm 204, \mathrm{n}=32)$, while, in the last 2 weeks of that month, gannets flew on average $33.8 \mathrm{~h}( \pm 14.6)$, covering $631 \mathrm{~km}( \pm 290, \mathrm{n}=20)$, an increase of 63 and $81 \%$, respectively. In general, trip duration increased as the breeding season progressed at Malgas, except in

Table 1. Morus capensis. Means \pm SD of foraging parameters of Cape gannets: per island for all years, and for Malgas and Ichaboe per year. Statistical results shown are from general linear models (GLMs) testing total distance, time spent flying, and time spent hunting. For trip duration and time drifting on the sea surface, Kruskal-Wallis test statistics $\left(\chi^{2}\right)$ or the Spearman correlation (rho) are shown. Significance at $0.05\left({ }^{*}\right)$ and $0.01\left({ }^{* *}\right)$ levels

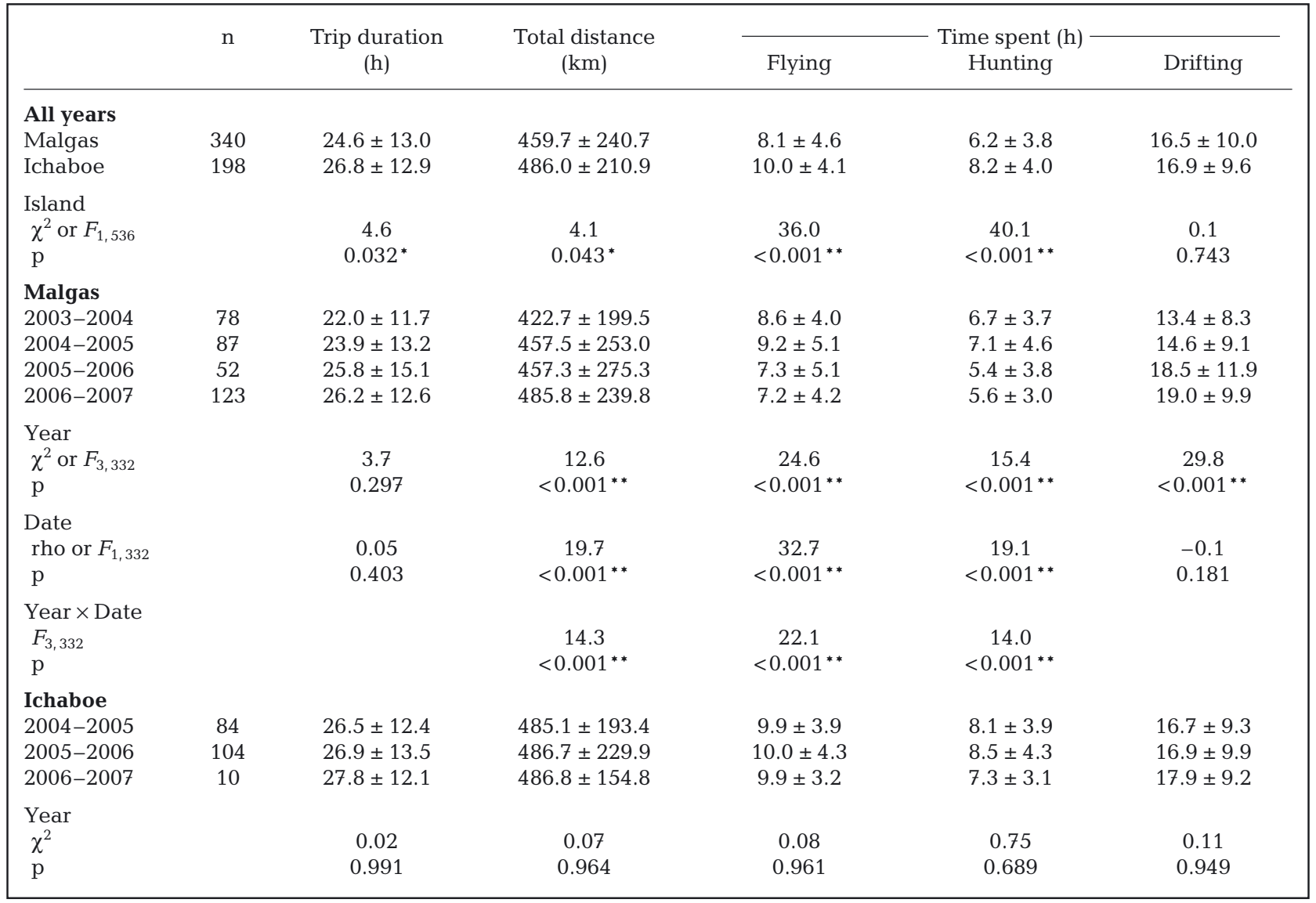


2004-2005 when it decreased (GLM: Year $F_{3,332}=7.2$, $\mathrm{p}<0.001$; Date $F_{1,332}=12.0, \mathrm{p}=0.001$; Year $\times$ Date $\left.F_{3,332}=8.2, \mathrm{p}<0.001\right)$.

Cape gannets breeding on Ichaboe showed little variation in any of the foraging parameters between years (Table 1c). Birds made trips of approximately $27 \mathrm{~h}$, covering an average of $486 \mathrm{~km}$. During these trips they flew for about $10 \mathrm{~h}$ and drifted, on average, $17 \mathrm{~h}$ at the sea surface. Also, within years, we found no significant variation in trip duration, or any other aspect of foraging behaviour on Ichaboe.

\section{Sex-specific foraging behaviour and body condition}

Female gannets made longer trips $(28.7 \pm 13.4 \mathrm{~h}, \mathrm{n}=$ $104)$ and covered more distance $(409 \pm 220 \mathrm{~km})$ during foraging than males $(23.9 \pm 11.0 \mathrm{~h}$ and $339 \pm 156 \mathrm{~km}$, respectively, $\mathrm{n}=97$; Table 2 ). Trips of females from Malgas were, on average, $6.5 \mathrm{~h} \mathrm{(28 \% )} \mathrm{longer} \mathrm{than} \mathrm{trips} \mathrm{of} \mathrm{males,}$ covering an extra $95 \mathrm{~km}(22 \%)$. At Ichaboe, the differences were smaller as female trip duration was only 1.1 $\mathrm{h}$ longer (4\%), flying an extra $63 \mathrm{~km} \mathrm{(14 \% )} \mathrm{compared} \mathrm{to}$ males. The difference in trip duration for birds from Malgas Island was mainly attributable to the extra $5 \mathrm{~h}$ that females spent drifting on the sea surface compared to males (Table 2). The relative time allocation during foraging trips, however, did not differ between the sexes on each island (Fig. 1). We found no differences between the sexes in the foraging sites visited.

Cape gannets from Malgas were, on average, $152 \mathrm{~g}$ heavier, had longer wings and a higher body condition index $\left(5.43 \pm 0.38 \mathrm{~g} \mathrm{~mm}^{-1}, \mathrm{n}=207\right)$ than birds from Ichaboe $\left(5.18 \pm 0.28 \mathrm{~g} \mathrm{~mm}^{-1}, \mathrm{n}=135\right)$. Female gannets were $100 \mathrm{~g}$ heavier than males (females: $2595 \pm 207 \mathrm{~g}$, $\mathrm{n}=113$; males: $2495 \pm 183 \mathrm{~g}, \mathrm{n}=104$ ), but the sexes did

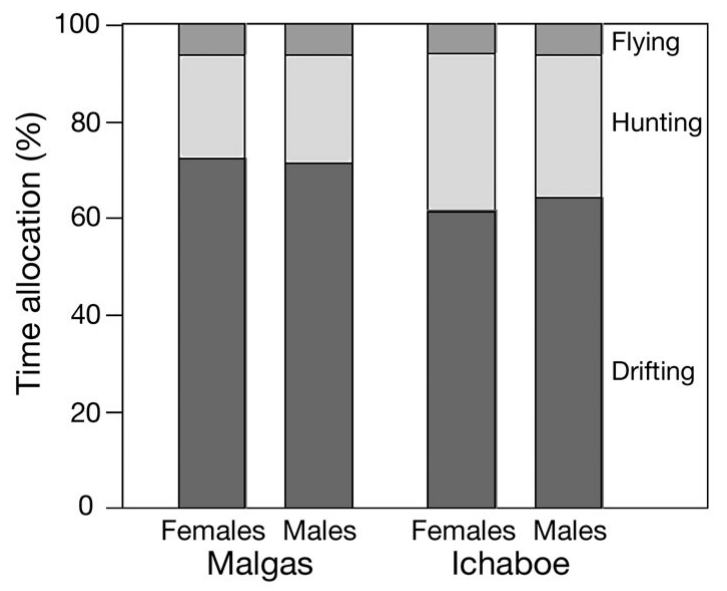

Fig. 1. Morus capensis. Percentage allocation of time to different activities by Cape gannets from Ichaboe and Malgas Islands during foraging trips. Flying: out-flights + returnflights; hunting: search flight with a high path sinuosity; drifting: time spent at the sea surface (see 'Materials and methods' for detailed definitions). Data are from 2005-2006 and 2006-2007 and sample sizes can be found in Table 1

not differ in wing length. Consequently, female body condition was $4 \%$ higher than that of males (GLMs: body mass: $\operatorname{sex} F_{1,214}=18.9, \mathrm{p}<0.001$; island $F_{1,214}=$ 41.1, $\mathrm{p}<0.001$; Wing length: Sex $F_{1,214}=0.09, \mathrm{p}=0.764$; Island $F_{1,215}=35.3, \mathrm{p}<0.001$; Body condition: $\operatorname{Sex} F_{1,214}$ $=21.0, \mathrm{p}<0.001$; Island $\left.F_{1,214}=26.4, \mathrm{p}<0.001\right)$.

\section{Foraging behaviour and diet choice}

Cape gannet diet did not differ between sexes or years, but varied between the colonies (multinomial regression: $\operatorname{Sex} \chi^{2}=1.8, p=0.769$; Year $\chi^{2}=0.2, p=0.995$;

Table 2. Morus capensis. Means \pm SD of foraging parameters of Cape gannets per island and per sex. Statistical results are shown for GLMs including sex and island for birds of known sex. For trip duration and time drifting on the sea surface Kruskal-Wallis test statistics $\left(\chi^{2}\right)$ are shown; for the other variables, the F-statistic is shown. Significance at $0.05\left({ }^{*}\right)$ and $0.01\left({ }^{* *}\right)$ levels. ns: not significant

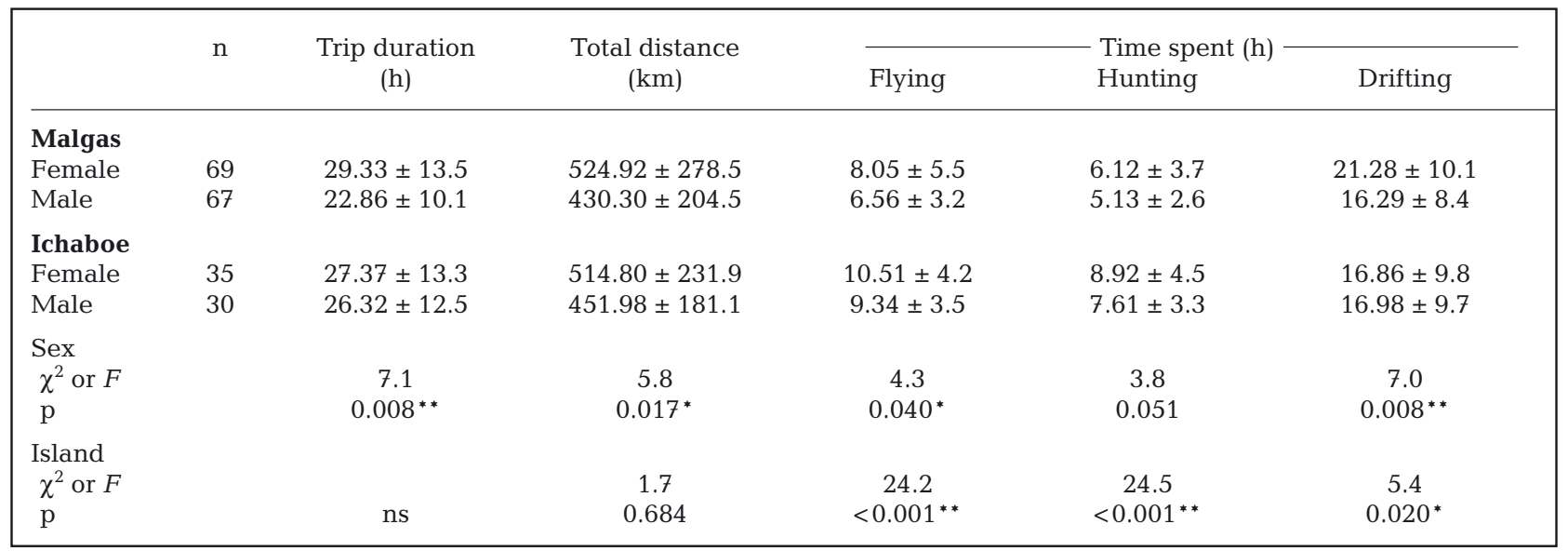




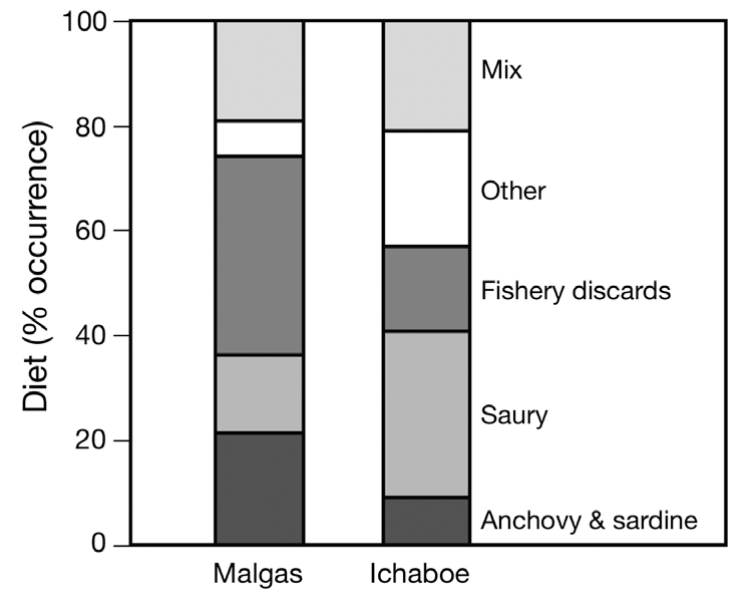

Fig. 2. Morus capensis. Diet (percent frequency of occurrence) of Cape gannets equipped with GPS-loggers during the 2005-2006 and 2006-2007 breeding seasons. Sample sizes are 74 for Malgas Island and 56 for Ichaboe Island. 'Other' includes horse mackerel Tracherus tracherus and snoek Thyrsites atun, and 'mix' contains diet samples with $>1$ prey species

Island $\chi^{2}=11.2, \mathrm{p}=0.024 ;$ Fig. 2 ). Fishery discards dominated the diet of gannets from Malgas, followed by anchovy and sardine. Gannets from Ichaboe mostly brought back saury or other live prey species, mainly snoek Thyrsites atun and horse mackerel Trachurus trachurus. In general, gannets that returned with live prey flew $145.2 \mathrm{~km}$ more $(39 \%)$, spent $3.8 \mathrm{~h}$ more in flight $(67 \%)$ and hunted for an extra $3.3 \mathrm{~h}(79 \%)$ compared to birds that scavenged behind trawlers (Table 3).

Gannets returning with fishery discards flew $3 \mathrm{~h}$ more during their trips at Ichaboe than at Malgas (8.0 \pm $2.0 \mathrm{~h}, \mathrm{n}=9 ; 5.0 \pm 1.9 \mathrm{~h}, \mathrm{n}=28$, respectively). Also, gannets from Ichaboe spent $10.1 \mathrm{~h}( \pm 3.6, \mathrm{n}=42)$ flying when foraging for live prey, compared to $8.9 \mathrm{~h}( \pm 6.1$, $\mathrm{n}=43$ ) for birds from Malgas.

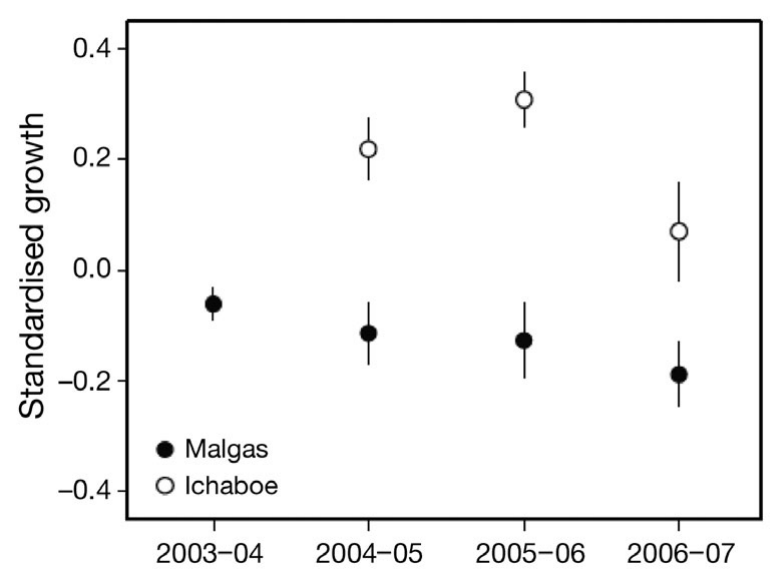

Fig. 3. Morus capensis. Standardised growth (number of SDs above or below the average growth rate) of Cape gannet chicks ( \pm 1 SE) at Ichaboe and Malgas Islands from 2003-2004 to 2006-2007. Sample sizes for Malgas Island are 152, 126, 135 and 80 chicks, respectively, and for Ichaboe Island are 98, 106 and 66 chicks, respectively

\section{Chick growth and foraging behaviour}

Chicks from Ichaboe showed faster growth rates than chicks from Malgas in each year (Fig. 3). Growth rates at Malgas decreased slightly over the 4 years. Chick growth on Ichaboe was reduced in 2006-2007 compared to in the 2 previous years. Within each year, chicks grew faster at the beginning of the breeding season than later (multi-level model: Island $\chi^{2}=92.6$, $\mathrm{p}<0.001$; Year $\chi^{2}=16.1, \mathrm{p}=0.001$; Date $\chi^{2}=33.0, \mathrm{p}<$ 0.001). In 2005-2006, fledglings from Ichaboe were, on average, $305 \mathrm{~g}$ heavier than chicks from Malgas (Ichaboe $2930 \pm 275 \mathrm{~g}, \mathrm{n}=107$; Malgas $2625 \pm 323 \mathrm{~g}, \mathrm{n}=$ 211; 1 -way ANOVA $F_{1,316}=69.6, \mathrm{p}<0.001$ ).

At Malgas Island, fledging success was $42 \%$ in 2003-2004 (percentage of nestlings fledged; Makhado

Table 3. Morus capensis. Means \pm SD of foraging parameters of Cape gannets, per diet category. Data are from 2005-2006 and 2006-2007. Results from GLMs with island and prey category as factors are also shown. Significance at $0.05\left(^{*}\right)$ and 0.01 $\left({ }^{* *}\right)$ levels

\begin{tabular}{|c|c|c|c|c|c|}
\hline & \multirow{2}{*}{$\mathrm{n}$} & \multirow{2}{*}{$\begin{array}{l}\text { Trip duration } \\
\text { (h) }\end{array}$} & \multirow{2}{*}{$\begin{array}{l}\text { Total distance } \\
\qquad(\mathrm{km})\end{array}$} & \multirow{2}{*}{\multicolumn{2}{|c|}{ 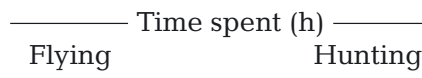 }} \\
\hline & & & & & \\
\hline Live prey & 85 & $27.3 \pm 12.0$ & $514.6 \pm 229.6$ & $9.5 \pm 5.0$ & $7.5 \pm 3.6$ \\
\hline Fish offal & 37 & $22.3 \pm 9.9$ & $369.2 \pm 133.8$ & $5.7 \pm 2.3$ & $4.2 \pm 2.0$ \\
\hline Mixed & 8 & $27.6 \pm 9.1$ & $498.4 \pm 185.4$ & $8.9 \pm 4.7$ & $7.0 \pm 3.3$ \\
\hline \multicolumn{6}{|l|}{ Island } \\
\hline$F$ & & 0.05 & 0.05 & 6.1 & 11.0 \\
\hline $\mathrm{p}$ & & 0.818 & 0.820 & $0.015^{*}$ & $0.001^{* *}$ \\
\hline \multicolumn{6}{|c|}{ Prey category } \\
\hline$F$ & & 2.6 & 6.6 & 7.0 & 10.3 \\
\hline $\mathrm{p}$ & & 0.078 & $0.002^{* *}$ & $0.001^{* *}$ & $<0.001^{* *}$ \\
\hline
\end{tabular}




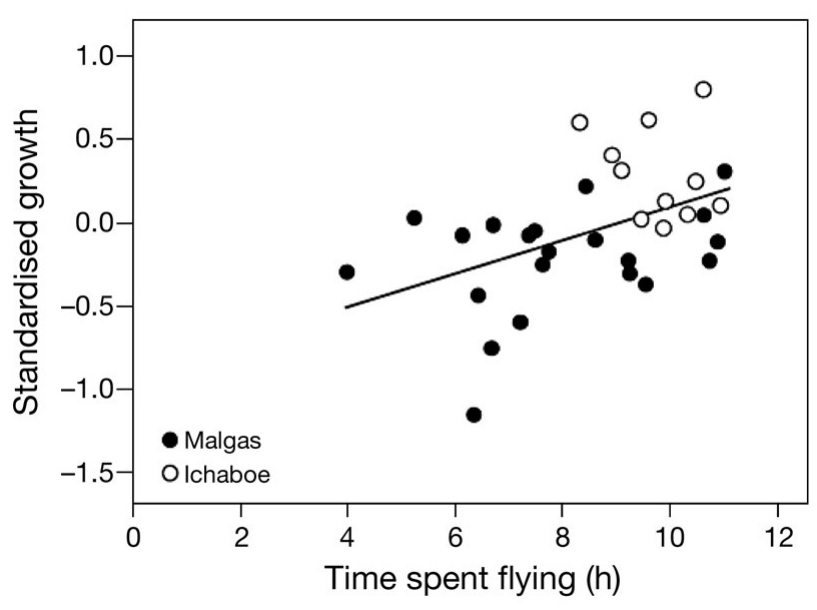

Fig. 4. Morus capensis. Relationship between standardised growth (number of SDs above or below the average growth rate) of Cape gannet chicks and time adults spent flying during foraging trips. Data are from Ichaboe and Malgas Islands from 2003-2004 to 2006-2007 when growth was measured

et al. 2006), and, at Ichaboe, fledging success was $68 \%$ ( $\mathrm{n}=53$ nests) in 2004-2005 and $87 \%(\mathrm{n}=23)$ in 20052006 (Ministry of Fisheries and Marine Resources, Namibia, unpubl. data).

Chick growth was positively correlated with the time spent flying during foraging trips, a relationship mainly due to differences between the 2 islands (Fig. 4). We found no correlation between any of the foraging variables and chick growth at particular islands (bivariate correlation, e.g. time spent flying; Malgas $\mathrm{r}=0.339, \mathrm{p}=0.132$; Ichaboe $\mathrm{r}=-0.241, \mathrm{p}=$ 0.475). Similar correlations were also tested at each island within years; only at Malgas in 2004-2005 were significant positive correlations found between foraging behaviours and chick growth (bivariate correlations: Trip duration $r=0.929, p=0.007$; Distance $r=$ 0.911, $\mathrm{p}=0.012$; Time spent flying $\mathrm{r}=0.922, \mathrm{p}=0.009$, $\mathrm{n}=6$ ). In GLMs, we tested the association between chick growth and trip duration, distance or time spent flying. In these analyses time spent flying during the foraging trips of adults was positively associated with chick growth, when corrected for island and date (GLM: Island $F_{1,28}=18.7, \mathrm{p}<0.001$; Date $F_{1,28}=5.8, \mathrm{p}$ $=0.023$; Time flying $F_{1,28}=4.5, \mathrm{p}=0.043$ ).

\section{DISCUSSION}

Under the threat of global changes it has now become crucially important to understand which factors are driving population dynamics, especially in species that are vulnerable to extinction. Conservation management would greatly benefit from variables that can be collected in a short time and are predictive for population dynamics at the time scale of a single reproductive season. We therefore tested the suitability of behavioural data as proxies for population health, as proposed by Lewis et al. (2006). From our results it is clear that data collected at the colony level are not reliable indicators for population status, and we should be cautious in using these proxies, at least in the Cape gannet Morus capensis.

\section{Seasonal variability in foraging behaviour in relation to diet}

A reduced availability since 1997 of inshore shoaling pelagic fish around Malgas Island (van der Lingen et al. 2005) has forced breeding Cape gannets to seek alternative prey. Early in the breeding season, birds scavenged for fishery discards. Birds that scavenged made shorter trips, flew less during trips and had smaller foraging areas than birds that brought back live prey. Later in the breeding season, saury Scomberesox saurus move closer inshore and become available to gannets (Berruti 1988, Berruti et al. 1993), and their proportion in the gannet diet increases. This may explain the general pattern of increases in foraging trip duration through breeding seasons. In 2 years we collected GPS data during 4 consecutive months. In 20032004, trip duration and distance covered increased during the breeding season, while in 2004-2005 these parameters decreased, disproving the generality of the patterns at Malgas. Short-term fluctuations in the distribution of prey fish (Shannon 1985) probably explain these deviations from the general pattern.

In contrast to Malgas, the environment around Ichaboe Island was less variable, as judged from the small inter- and intra-annual variation in foraging behaviour of breeding gannets. Anchovies Engraulis encrasicolus and sardines Sardinops sagax have been scarce in Namibian waters since the late 1960s (Crawford 2007). Live prey, mainly horse mackerel Trachurus trachurus, was available as an alternative for anchovies and sardines throughout the breeding season. Judged from the longer foraging trips when returning with live prey compared to gannets from Malgas, overall food availability might have been lower around Ichaboe (Boyd et al. 1994, Suryan et al. 2002). The availability of live prey was likely more predictable, as their overall proportion was larger in the diet of Ichaboe gannets. Gannets from Ichaboe made longer foraging trips than birds from Malgas, despite a lower average body condition. The higher proportion of live prey in the diet of gannets from Ichaboe and the associated larger energetic and fat content (Batchelor \& Ross 1984, FAO 1989) could facilitate higher levels of foraging effort (Weimerskirch et al. 2001). 


\section{Sex-specific foraging behaviour}

Female Cape gannets made longer foraging trips and covered more distance than males, but during foraging trips both sexes allocated their time similarly between behaviours (Fig. 1). These results are consistent with data on nest attendance (Mullers \& Tinbergen 2009) and demonstrate sex-specific foraging behaviour in a monomorphic species (Gray \& Hamer 2001, Lewis et al. 2002). We found no differences in the location of foraging areas or diet between the sexes, and there was no difference in the amount of food brought back to the nest either (females $542 \pm 135 \mathrm{~g}$, $\mathrm{n}=12$; males $597 \pm 105 \mathrm{~g}, \mathrm{n}=12$; L. Pichegru unpubl. data). Hence, female gannets needed more time to bring back the same amount of the same kind of food than males, which may suggest a lower foraging efficiency, or differences in resource allocation between the sexes (Weimerskirch et al. 1997). For example, females may require more self feeding to compensate for energy loss during egg laying and incubation (Monaghan \& Nager 1997). In the related northern gannets Morus bassanus, the sexes did not differ significantly in trip duration, but females made longer and deeper dives (Lewis et al. 2002), suggesting different foraging strategies. We need detailed data on the diving behaviour of Cape gannets to explore the differences in foraging behaviour between the sexes.

\section{Foraging behaviour and chick growth in relation to diet}

Cape gannet chicks from Ichaboe Island grew faster, were heavier at fledging and had higher fledging rates than Malgas chicks. Despite considerable intraseasonal variation in both parental behaviour and chick growth, we found no correlations between these variables at particular islands, except at Malgas in 2004-2005. However, after correcting for the variation explained by differences in conditions between the colonies and during the breeding season, chick growth was positively associated with hours spent flying during foraging trips. This non-intuitive relationship may be mediated through diet; gannets that spent more time flying were more likely to forage for live prey, which is of better quality (energy content: sardine $8.59 \mathrm{~kJ} \mathrm{~g}^{-1}$; anchovy $6.74 \mathrm{~kJ} \mathrm{~g}^{-1}$; hake (fishery discards) $4.07 \mathrm{~kJ} \mathrm{~g}^{-1}$; Batchelor \& Ross 1984, FAO 1989) and enhances growth rates (Batchelor \& Ross 1984, Mullers et al. 2009a). Gannet parents that feed on fishery discards bring back larger quantities than live prey, but not enough to sustain their own energy requirements and those of their growing young (Pichegru et al. 2007). Feeding offspring with 'junk' food can have large negative effects on chick growth and survival (Annett \& Pierotti 1999, Mullers et al. 2009a), which ultimately will decrease recruitment rates.

In Cape gannets the proportion of flying during foraging trips is positively associated with energy expenditure (Mullers et al. 2009b). In the present study, the proportion of flying during trips was 33 and $37 \%$ for Malgas and Ichaboe Islands, respectively. We do not have time budgets from both islands to estimate daily energy expenditure, but we can conclude that during foraging trips, gannets from Ichaboe spent more energy, which was associated with faster chick growth. It seems that parents from Ichaboe were able to acquire more energy, both for their own energy expenditure and to sustain a faster growth of their chick. Again, the better quality of their diet and a more predictable availability of their food source might sustain this larger energy expenditure.

\section{Foraging variables as indicators for population health status}

The health status of a colony is defined here as the growth rate of a breeding colony (cf. Lewis et al. 2006). Based on the population numbers presented in Table 1 of Crawford et al. (2007), we calculated the growth rates for Malgas and Ichaboe Islands between 20012002 and 2005-2006. At Malgas, the population decreased from 48058 to 36156 breeding pairs, and at Ichaboe, the population decreased from 13268 to 8669 (Crawford et al. 2007); these figures represent 6.2 and $8.7 \%$ decreases per annum, respectively. Accordingly, the Malgas population was in better 'health' than the Ichaboe population.

Lewis et al. (2006) found a negative relationship between foraging trip length and population growth in Cape gannets. These conclusions hinge on putative population increases by the Malgas and Lambert's Bay colonies, as shown in their Fig. 1. However, examination of the time series reported by Crawford et al. (2007) reveals that both colonies have been steadily decreasing from 1996-1997 until the present (2005/ 2006). As a result, the relationship between population growth (i.e. indicator for population health) and trip duration in the study of Lewis et al. (2006) would be similar to ours; in colonies that decrease fastest, parents make longer trips. The duration of foraging trips is not a direct measure of colony health, and, therefore, should be associated with reproductive parameters. We found no correlation between trip duration and chick growth, but we did find a positive association between hours spent flying during trips and chick growth. We already suggested that this might be mediated through the diet, but perhaps this also indicates 
that, when food is poor around colonies, birds choose to maintain their own body condition rather than diverting energy to reproductive effort (Bijleveld \& Mullers 2009).

Most studies on population dynamics treat individuals in a population as ecologically equivalent. Within populations, however, there are large inter-individual differences in behavioural strategies, which ultimately affect breeding success (Bolnick et al. 2003). Mullers \& Tinbergen (2009) showed that an individual approach in Cape gannets was more promising, because longitudinal behavioural data on individuals collected at the nest were associated with the growth and survival of their offspring. Cape gannet pairs that made shorter foraging trips, and thus visited the nest more often, had chicks that grew faster and had higher survival rates, as predicted by Lewis et al. (2006). It seems that only the direct effect of parental behaviour on the reproductive performance of their own offspring might yield some predictive value related to 'colony health'.

Another problem is the lag between the reproductive output during a breeding season and the recruitment into the breeding colony when young reach maturity. Cape gannets breed for the first time when they are 3 or 4 yr old (Nelson 1978), and patterns between state variables and population trends depend on which data are selected. At the same time, other processes in the colony, like predation pressure, affected parental behaviour and ultimately chick growth and survival (Mullers \& Tinbergen 2009). At Malgas, predation by kelp gulls Larus dominicanus (authors' pers. obs.), great white pelicans Pelecanus onocrotalus (de Ponte Machado 2007) and Cape fur seals Arctocephalus pusillus pusillus (Makhado et al. 2006) on the eggs, chicks and recently fledged young of Cape gannets increased dramatically over the last few years. We therefore conclude that the behavioural parameters collected at the colony level, like duration of foraging trips, are not a good proxy for estimating colony health.

\section{Conclusions}

If we want to use behavioural data at the population level to indicate colony health, these data should be consistent throughout the breeding season and robust under different circumstances, e.g. during periods of increased predation pressure. In Cape gannets, these assumptions are not met; therefore, it is doubtful that behavioural variables collected at the colony level alone can be used as proxies for colony health status. Data on the foraging behaviour of parents and the growth of their chicks help to understand the potential health status of colonies, but a complete demographic analysis is needed, if we are to fully understand the recent changes in the breeding populations of Cape gannets.

Acknowledgements. We thank A. Bijleveld, F. Hermanides, M. Perk, L. Pichegru and J. van der Woude for help in the field. SANParks and MFMR provided transport to and from the islands. A warm thanks to L. Pichegru for sharing her data on food loads. R. Crawford, S. Daan, J. Tinbergen and 3 anonymous referees made valuable comments on the manuscript. R.H.E.M. was funded by the Netherlands Foundation for the Advancement of Tropical Research (WOTRO). R.A.N. acknowledges support from the National Research Foundation, Pretoria. The present paper is a contribution to the project LMR/EAF/03/02 on top predators of the Benguela Current Large Marine Ecosystem (BCLME) Programme. All research was conducted under permits of SANParks in South Africa and the Namibian Ministry of Fisheries and Marine Resources (MFMR).

\section{LITERATURE CITED}

Adams NJ, Klages NTW (1999) Foraging effort and prey choice in Cape gannets. S Afr J Mar Sci 21:157-163

Annett CA, Pierotti R (1999) Long-term reproductive output in western gulls: consequences of alternate tactics in diet choice. Ecology 80:288-297

Batchelor AL, Ross GJB (1984) The diet and implications of dietary change of Cape gannets on Bird Island, Algoa Bay. Ostrich 55:45-63

Berruti A (1988) Distribution of and predation on saury Scomberesox saurus scombroides in continental-shelf waters off the Cape province, South Africa. S Afr J Mar Sci 6:183-192

Berruti A, Underhill LG, Shelton PA, Moloney C, Crawford RJM (1993) Seasonal and interannual variation in the diet of 2 colonies of the Cape gannet (Morus capensis) between 1977-78 and 1989. Colon Waterbirds 16:158-175

Bijleveld AI, Mullers RHE (2009) Reproductive effort in biparental care: an experimental study in long-lived Cape gannets. Behav Ecol 20:736-744

Bolnick DI, Svanbäck R, Fordyce JA, Yang LH, Davis JM, Hulsey CD, Forister ML (2003) The ecology of individuals: incidence and implications of individual specialization. Am Nat 161:1-28

Boyd IL, Arnould JPY, Barton T, Croxall JP (1994) Foraging behavior of Antarctic fur seals during periods of contrasting prey abundance. J Anim Ecol 63:703-713

Crawford RJM (2007) Food, fishing and seabirds in the Benguela upwelling system. J Ornithol 148:253-260

Crawford RJM, Dundee BL, Dyer BM, Klages NTW, Meyer MA, Upfold L (2007) Trends in numbers of Cape gannets (Morus capensis), 1956/1957-2005/2006, with a consideration of the influence of food and other factors. ICES J Mar Sci 64:570-576

de Ponte Machado M (2007) Is predation on seabirds a new foraging behaviour for great white pelicans? History, foraging strategies and prey defensive responses. In: Kirkman SP (ed) Final report of the BCLME (Benguela Current Large Marine Ecosystem) project on top predators as biological indicators of ecosystem change in the BCLME. Animal Demography Unit, University of Cape Town, Cape Town, p 131-142

> Falk K, Benvenuti S, Dall'Antonia L, Gilchrist G, Kampp K (2002) Foraging behaviour of thick-billed murres breeding 
in different sectors of the North Water polynya: an intercolony comparison. Mar Ecol Prog Ser 231:293-302

FAO (Food and Agricultural Organization) (1989) Yield and nutritional value of the commercially more important fish species. FAO Fish Tech Pap 309:1-187

Fridolfsson AK, Ellegren H (1999) A simple and universal method for molecular sexing of non-ratite birds. J Avian Biol 30:116-121

Gray CM, Hamer KC (2001) Food-provisioning behaviour of male and female Manx shearwaters, Puffinus puffinus. Anim Behav 62:117-121

Grémillet D, Dell'Omo G, Ryan PG, Peters G, Ropert-Coudert Y, Weeks SJ (2004) Offshore diplomacy, or how seabirds mitigate intra-specific competition: a case study based on GPS tracking of Cape gannets from neighbouring colonies. Mar Ecol Prog Ser 268:265-279

Krebs CJ (1995) Two paradigms of population regulation. Wildl Res 22:1-10

Krebs CJ (2002) Two complementary paradigms for analysing population dynamics. Philos Trans R Soc Lond, B 357: 1211-1219

Lebreton JD, Burnham KP, Clobert J, Anderson DR (1992) Modeling survival and testing biological hypotheses using marked animals: a unified approach with case-studies. Ecol Monogr 62:67-118

Lewis S, Benvenuti S, Dall'Antonia L, Griffiths R and others (2002) Sex-specific foraging behaviour in a monomorphic seabird. Proc Biol Sci 269:1687-1693

Lewis S, Gremillet D, Daunt F, Ryan PG, Crawford RJM, Wanless S (2006) Using behavioural and state variables to identify proximate causes of population change in a seabird. Oecologia 147:606-614

Makhado AB, Crawford RJM, Underhill LG (2006) Impact of predation by Cape fur seals Arctocephalus pusillus pusillus on Cape gannets Morus capensis at Malgas Island, Western Cape, South Africa. Afr J Mar Sci 28:681-687

Monaghan P, Nager RG (1997) Why don't birds lay more eggs? Trends Ecol Evol 12:270-274

Mullers RHE, Tinbergen JM (2009) Parental provisioning behaviour predicts survival of Cape gannet chicks under poor conditions. Ardea 97:89-98

Mullers RHE, Navarro RA, Crawford RJM, Underhill LG (2009a) The importance of lipid-rich fish prey for Cape gannet chick growth: Are fishery discards an alternative? ICES J Mar Sci 66:2244-2252

Mullers RHE, Navarro RA, Daan S, Tinbergen JM, Meijer HAJ (2009b) Energetic costs of foraging in breeding Cape gannets Morus capensis. Mar Ecol Prog Ser 393: 161-171

Editorial responsibility: Jonathan Green, Liverpool, UK
Nelson JB (1978) African or Cape gannet. In: The Sulidae. Gannets and boobies. University Press, Oxford, p 231-265

Pichegru L, Ryan PG, van der Lingen CD, Coetzee JC, Ropert-Coudert Y, Gremillet D (2007) Foraging behaviour and energetics of Cape gannets Morus capensis feeding on live prey and fishery discards in the Benguela upwelling system. Mar Ecol Prog Ser 350:127-136

Pradel R, Johnson AR, Viallefont A, Nager RG, Cezilly F (1997) Local recruitment in the greater flamingo: a new approach using capture-mark-recapture data. Ecology 78 : 1431-1445

Pugesek BH (1995) Offspring growth in the California gull: reproductive effort and parental experience hypotheses. Anim Behav 49:641-647

Ropert-Coudert Y, Grémillet D, Kato A, Ryan PG, Naito Y, Le Maho Y (2004) A fine-scale time budget of Cape gannets provides insights into the foraging strategies of coastal seabirds. Anim Behav 67:985-992

Shannon LV (1985) The Benguela ecosystem. 1. Evolution of the Benguela, physical features and processes. Oceanogr Mar Biol Annu Rev 23:105-183

Snyder JP (1987) Map projections: a working manual. Prof Pap US Geol Surv 1395:1-385

Steiner I, Bürgi C, Werffeli S, Dell'Omo G and others (2000) GPS logger and software for analysis of homing in pigeons and small mammals. Physiol Behav 71:589-596

Suryan RM, Irons DB, Kaufman M, Benson J, Jodice PGR, Roby DD, Brown ED (2002) Short-term fluctuations in forage fish availability and the effect on prey selection and brood-rearing in the black-legged kittiwake Rissa tridactyla. Mar Ecol Prog Ser 236:273-287

Takahashi A, Watanuki Y, Sato K, Kato A, Arai N, Nishikawa J, Naito Y (2003) Parental foraging effort and offspring growth in Adélie penguins: Does working hard improve reproductive success? Funct Ecol 17:590-597

van der Lingen CD, Coetzee JC, Demarcq H, Drapeau L, Fairweather TP, Hutchings L (2005) An eastward shift in the distribution of southern Benguela sardine. Globec Int Newsletter 11:17-22

Weimerskirch H, Cherel Y, Cuenot-Chaillet F, Ridoux V (1997) Alternative foraging strategies and resource allocation by male and female wandering albatrosses. Ecology 78:2051-2063

Weimerskirch H, Zimmermann L, Prince PA (2001) Influence of environmental variability on breeding in a long-lived seabird, the yellow-nosed albatross. Behav Ecol 12:22-30

Wendeln H, Becker PH (1999) Effects of parental quality and effort on the reproduction of common terns. J Anim Ecol 68:205-214

Submitted: July 14, 2009; Accepted: July 28, 2010

Proofs received from author(s): August 26, 2010 